\title{
EFFECT OF FEEDING ON SWEET OR SALINE WATER KOCHIA AS A FODDER IN GROWING RABBITS RATIONS.
}

\author{
H.M. Elsayed ${ }^{1}$; A.A. Marwan ${ }^{1}$ and Y. I. Ibrahim ${ }^{2}$ \\ ${ }^{1}$ Faculty of Agriculture, Ain Shams University, Shoubra El-Khyma, Cairo, Egypt, \\ ${ }^{2}$ Ministry of Health and Population, Cairo, Egypt
}

(Received 11/4/2017, accepted 17/5/2017)

\section{SUMMARY}

$\mathrm{T}$

Twenty four, 4 weeks of age weaning rabbits were used in this study. These rabbits immediately after weaning were assigned into three experimental groups ( 8 animals each) 4 males and 4 females in the beginning of their fifth week till the end of eleventh week of age, The animals were divided randomly and fed proportion offresh, saline water kochia and granular feed, whereas, rabbits of the first group (control group, G1) were fed on $100 \%$ basal granular feed (maintenance and growth requirements) formulated according to NRC (1977) recommendations. While G2 were fed $100 \%$ freshwater-kochia (maintenance and growth), G3 were fed 25\% saline water kochia, $75 \%$ freshwater-kochia for growth requirement, while fed granular feed to cover maintenance requirement. The results showed that the group which fed $100 \%$ granular feed (G1) showed the highest value of average daily gain and daily feed intake $(\mathrm{P} \leq 0.05)$ compared to the other groups, while G3 had a poorest (highest) values $(\mathrm{p}<0.05)$ of feed conversion. Also, results revealed that the rabbits fed diets contained fresh and/or saline kochia had the higher values of economic efficiency, relative economic efficiency and had the lower values of daily feed cost LE/head. This result indicated that utilizing fresh and/or saline water to produce halophytes fodder (kochia) could be an avenue to minimize the feedstuff shortage, feed cost and increase feed efficiency.

Keywords: halophytes, saline water, kochia, rabbits, growth performance, feed efficiency and economic efficiency.

\section{INTRODUCTION}

Water is the basic substance of life on earth, and it is increasingly in short supply. Water shortages affect 88 developing countries that are home to half of the world's population in these places (Miller, 2003).

Khalifa (2005) stated that the major dilemma the world faces is how to increase and sustain productivity of irrigated agriculture while reducing the sector's water consumption. In other words, the challenge will be to produce more food with less water. The easily accessible water resources, surface and groundwater, of good quality have now been almost entirely committed. Moreover, Anon (2009) and El Shaer (2010) reported that the interest in search for alternative/additional feed ingredients is of paramount importance in developing countries, mainly, because of the acute shortage of traditional feed materials. Introduction of saline agriculture production systems in salt affected regions has proved to be an effective way to save fresh water for human and animal consumption while the saline water could be used for animal feed production.

In addition, Al-Dabbas (2001) and Hamdy (2001) illustrated that the use of non-conventional water resources is increasingly playing a major role in the development of agriculture and this will help in the conservation of the good quality water and make it available for other uses.

Egypt has already exhausted its fixed nile water share, and the groundwater requires expensive energy to abstract more and costs to transport. The allocation of the total water resources among agriculture, industry and domestic uses are within the ratio of $85 \%, 9 \%$ and $6 \%$ respectively (Bayoumi et al., 2010). In addition, several salt tolerant plant species have been introduced in south Sinai Governorate to be grown in saline soils and irrigated with saline ground water (Anon, 2006). 


\section{Elsayed et al.}

Semioshkina et al. (2007) illustrated that small animals such as rabbits or chickens are an important source of protein for a large number of people around the world. The requirements for their husbandry concerning capital and feed are low, and they are especially popular with people on low incomes.

Catherine and Hubert (2005) stated that in commercial rabbit production, feed consumption is one of the critical points: feed costs represent over $70 \%$ of rabbit meat production.

The present study aimed to investigate saline water kochia as halophytes fodder to be a feasible solution to minimize the problems of shortage of feed, feed cost and fresh water shortage especially in arid and semi-arid regions and to evaluate the nutritive quality and nutritional performance of rabbits fed kochia (Kochia scoparia) as a halophytic plant as a sole diet or mixed with a concentrate rabbit diet.

\section{MATERIALS AND METHODS}

\section{Experimental Feeds:}

\section{Kochia:}

Kochia scoparia belongs to the family Chenopodiaceae. It was establishedin America in the early 1900 's. Kochia grows well in a great variety of climates and soils. Kochia is annual, reproduces by seeds. Stems are erect, light green and highlybranched (Undersander et al., 2004).

Kochia has a short vegetative cycle, 70 day to the time for cutting (early flowering stage), with low water requirement $(30-50 \mathrm{~cm})$; and high yields $(24 \mathrm{ton} / \mathrm{ha})$ of dry matter; it has high protein content (18$26 \%$ ) and good palatability. Kochia has high yield potential with higher mineral content than most conventional hays, particularly when grown on saline soils (Ajjour, 2005).

Field kochia was found in El Fayom desert road in Dahshour area in front of military camp about 6 Carats was plant by Agriculture sowing method mixture of sand water resource was saline water 10.000 ppm from saline well, non- fertilizer added.Three times of Harvesting was established, first time was after 45 day from plantation, second time was after 21 day from first harvest, third harvest was after 21 day from second harvest.Kochia was irrigated by two types of water, fresh water (FW)and saline water (SW) and introduced to animals as two types of kochia.

\section{Granular feed:}

This was consisted of composed of $14 \%$ yellow corn, $12 \%$ soybean meal, $32 \%$ wheat bran,30\% berseem hay, $7 \%$ barley grains, $3 \%$ molasses, $0.3 \%$ salts, $0.3 \%$ mineral salts, $0.11 \%$ methionine, $0.02 \%$ lysine and $1.28 \%$ limestone according to the feeding regime of the farm, whereas, the control group (G1) were fed the basal ration without any additives. Chemical compositions of feedstuffs are illustrated in Table (1).

Table (1). Chemical composition of feed stuffs ( $\%$ as fed).

\begin{tabular}{lccccccc}
\hline Item & DM & OM & CF & CP & EE & NFE & Ash \\
\hline Granular feed & 89.7 & 77.59 & 10.28 & 15.00 & 2.16 & 50.15 & 12.11 \\
Kochia & 87.8 & 78.35 & 27.48 & 8.50 & 1.58 & 40.79 & 9.45 \\
\hline
\end{tabular}

\section{ExperimentalAnimals:}

Twenty four (12 males and 12 females), 4 weeks of age weaning rabbits were used in this study. These rabbits immediately after weaning were assigned into three similar groups ( 8 animals each) 4 males and 4 females in the beginning of fifth week of age till eleventh. Animals of each group fed proportion of fresh or saline kochia and/or granular feed as following:

- G1 was fed as $100 \%$ granular feed (growth and maintenance requirements)

- G2 was fed as $100 \%$ fresh kochia (growth+ maintenance) from fifth to eleventh weak.

- G3 was fed as 25\% saline kochia, $75 \%$ fresh kochia (Growth), in addition to Granular feed to cover maintenance requirements

Rabbits were housed separately in individual wired cages. Diets were offered twice daily in equal quantities at the 8 am and $4 \mathrm{pm}$ and estimated for each of the three groups every day. Rabbit's drinking 
water by the nipples (automatic drinkers), this system provided animals with fresh water all over the experimental period. Rabbits in all treatment groups were kept under similar managerial system and environmental conditions.

\section{Soil analysis:}

Chemical analysis for soilabstracts was illustrated in Table (2) to reveal percentage ofcalcium carbonate and organic matter.

\section{Water analysis:}

Chemical analysis for irrigation water was illustrated in Table (3)

Table (2) Chemical analysis for soil abstracts

\begin{tabular}{|c|c|c|c|c|c|c|c|c|c|c|c|c|}
\hline \multirow{2}{*}{$\mathrm{pH}$} & \multirow{2}{*}{$\mathrm{EC}(\mathrm{ds} / \mathrm{m})$} & \multirow{2}{*}{ SP } & \multicolumn{4}{|c|}{ Anion (mg/L) } & \multicolumn{4}{|c|}{ Cat ion $(\mathrm{mg} / \mathrm{L})$} & \multirow{2}{*}{$\mathrm{CaCO}_{3} \%$} & \multirow{2}{*}{$\begin{array}{c}\text { O.M } \\
\%\end{array}$} \\
\hline & & & $\mathrm{CO}_{3}^{-}$ & $\mathrm{HCO}_{3}^{-}$ & $\mathrm{Cl}^{-}$ & $\mathrm{SO}_{4}^{-}$ & $\mathrm{Ca}^{++}$ & $\mathrm{Mg}^{++}$ & $\mathrm{Na}^{+}$ & $\mathrm{K}^{+}$ & & \\
\hline 8.05 & 5.50 & 31.88 & - & 4.4 & 40.6 & 16.5 & 23.75 & 9.25 & 19.4 & 1.1 & 11.8 & 0.39 \\
\hline
\end{tabular}

Table (3). Chemical analysis for irrigation water

\begin{tabular}{|c|c|c|c|c|c|c|c|c|c|c|c|c|c|}
\hline \multirow{2}{*}{$\begin{array}{l}\text { Sample } \\
\text { no. }\end{array}$} & \multirow{2}{*}{$\mathrm{pH}$} & \multirow{2}{*}{$\mathrm{EC}(\mathrm{ds} / \mathrm{m})$} & \multirow{2}{*}{$\begin{array}{l}\text { TDS } \\
(\mathrm{ppm})\end{array}$} & \multicolumn{4}{|c|}{ Anion(mg/L) } & \multicolumn{4}{|c|}{ Cat ion $(\mathrm{mg} / \mathrm{L})$} & \multirow{2}{*}{$\begin{array}{c}\mathrm{NaCO}_{3} \\
\%\end{array}$} & \multirow{2}{*}{$\begin{array}{c}\text { Na ads } \\
\%\end{array}$} \\
\hline & & & & $\mathrm{CO}_{3}^{-}$ & $\mathrm{HCO}_{3}^{-}$ & $\mathrm{Cl}^{-}$ & $\mathrm{SO}_{4}^{-}$ & $\mathrm{Ca}^{++}$ & $\mathrm{Mg}^{++}$ & $\mathrm{Na}^{+}$ & $\mathrm{K}^{+}$ & & \\
\hline 1 & 7.29 & 34.95 & 27960 & - & 5.6 & 321 & 16.6 & 35 & 70 & 236 & 2.24 & - & 32.6 \\
\hline
\end{tabular}

\section{Analytical methods}

The chemical composition of the feedstuffs were analyzed according to the A.O.A.C. (1995) methods to determine moisture, DM, OM, CP, CF, EE, and ash contents, while NFE content was calculated by difference.

\section{Statistical Analysis:}

The data were analyzed according to statistical analysis system SAS User s Guide (SAS 1995). Separation among means was carried out by using Duncan multiple tests, (Duncan 1955).

\section{RESULTS AND DISCUSSION}

\section{Growth performance and feed conversion}

Regarding to growth performance and feed conversion of experimental rabbits, the data show that a significant $(\mathrm{P} \leq 0.05)$ differences were observed in average daily gain due to treatment between different groups (Table 4). The mean values of average daily gain were 19.74, 13.97, and 9.24 (g/h/day) for G1, G2 and G3, respectively. Results show that averages of daily feed intake were higher $(\mathrm{P} \leq 0.05)$ for group was fed $100 \%$ granular feed (growth and maintenance requirements) G1 (control group) than the other groups. The values of daily feed intake were $95.76,70.70$, and 67.07 (g/h/day) for G1, G2 and G3, respectively. Data of Table (5) showed a significant $(\mathrm{P} \leq 0.05)$ differences in Initial weight among the different groups. The data show that the highest value $(\mathrm{P} \leq 0.05)$ of initial weight was recorded for $\mathrm{G} 1$ compared to the other groups $(\mathrm{G} 2$ and $\mathrm{G} 3)$. The highest value $(\mathrm{P} \leq 0.05)$ of Final weight was recorded for all the same group (G1). Furthermore, the data show that a significant $(\mathrm{P} \leq 0.05)$ differences were observed in total gain among the different groups. Concerning feed conversion ratio, data of Table (4) indicated that averages feed conversion were better $(\mathrm{P} \leq 0.05)$ for group fed $100 \%$ fresh kochia (growth+ maintenance) G1 and G2 than group G3. 
Table (4): Effect of experimental treatments on growth performance and feed conversion in rabbits during the entire experimental period.

\begin{tabular}{|c|c|c|c|}
\hline Item & G1 & G2 & G3 \\
\hline \multicolumn{4}{|c|}{ Daily body gain $(\mathrm{g})$ : } \\
\hline 2 weeks & $20.50 \pm 0.37$ & $11.83 \pm 0.44$ & $9.17 \pm 0.48$ \\
\hline 4 weeks & $24.79 \pm 0.38$ & $16.48 \pm 1.41$ & $7.05 \pm 0.90$ \\
\hline 6 weeks & $13.92 \pm 1.18$ & $13.90 \pm 1.44$ & $11.89 \pm 1.60$ \\
\hline Average & $19.74^{\mathrm{a}}$ & $13.97^{\mathrm{b}}$ & $9.24^{\mathrm{c}}$ \\
\hline \multicolumn{4}{|c|}{ Daily feed intake $(\mathrm{g})$ : } \\
\hline 2 weeks & 74.79 & 52.63 & 53.42 \\
\hline 4 weeks & 104.17 & 70.32 & 66.10 \\
\hline 6 weeks & 108.33 & 89.14 & 81.69 \\
\hline Average & $95.76^{\mathrm{a}}$ & $70.70^{\mathrm{b}}$ & $67.07^{\mathrm{c}}$ \\
\hline \multicolumn{4}{|c|}{ Feed conversion (feed/gain): } \\
\hline 2 weeks & $3.66 \pm 0.07$ & $4.49 \pm 0.17$ & $5.94 \pm 0.30$ \\
\hline 4 weeks & $4.21 \pm 0.07$ & $4.44 \pm 0.35$ & $10.84 \pm 1.94$ \\
\hline 6 weeks & $8.18 \pm 0.68$ & $7.06 \pm 1.09$ & $7.40 \pm 0.79$ \\
\hline Average & $5.35^{\mathrm{b}}$ & $5.29^{c}$ & $7.99^{\mathrm{a}}$ \\
\hline
\end{tabular}

Table (5): Effect of experimental treatments on initial weight, final weight and total gain in rabbits during the entire experimental period.

\begin{tabular}{lccc}
\hline Item & $\mathrm{G} 1$ & $\mathrm{G} 2$ & $\mathrm{G} 3$ \\
\hline Initial Weight $(\mathrm{g})$ & $605.63^{\mathrm{a}} \pm 11.67$ & $603.75^{\mathrm{ab}} \pm 9.72$ & $567.50^{\mathrm{b}} \pm 20.22$ \\
Final Weight $(\mathrm{g})$ & $1493.75^{\mathrm{a}} \pm 20.87$ & $1237.14^{\mathrm{b}} \pm 10.17$ & $1020.00^{\mathrm{c}} \pm 16.53$ \\
Total Gain $(\mathrm{g})$ & $888.13^{\mathrm{a}} \pm 16.88$ & $629.29^{\mathrm{b}} \pm 10.66$ & $434.17^{\mathrm{c}} \pm 16.65$ \\
\hline$a, b, \ldots$ Means of treatments within the same row with different superscript letters are differ significantly $(P \leq 0.05)$ \\
- G1 = fed 100\% granular feed (growth and maintenance requirements), G2 = fed 100\% fresh kochia (growth+ \\
maintenance) from fith to eleventh weak, G3 = fed 25\% saline kochia, $75 \%$ fresh kochia (Growth), in addition to \\
Granular feed to cover maintenance requirements
\end{tabular}

The present results agree with those obtained by Mohammady et al (2014) in an experiment on Forty Barki ewes divided into 2 groups (20 each). Group 1 (G1) received berseem hay and concentrate feed mixture (control), while group 2 (G2) received halophytic silage and concentrate feed mixture. They reported that average DMI per head was found $(292.8 \mathrm{~kg}$ vs. $274.1 \mathrm{~kg}$ ) for G1 and G2, respectively throughout the experimental period (298 days) whereas average daily gain of lambs were $(0.120$ and $0.087 \mathrm{~kg}$ ) for G1 and G2, respectively. The same results were obtained by Shaker (2014) who divided eighteen Barki sheep into two equal groups, the first group (G1) was fed berseem hay and served as control and the second group (G2) was fed a mixture of Atriplex nummularia, sorghum bicolor and Pearl millethe. He recorded that the animals fed control diet (control group) had insignificant higher final body weight and daily gain as compared to their counterparts of treatment. Furthermore, Zarkawi et al. (2005) reported that Awassi ewes fed Sesbania aculeate which grown on salty soil and irrigated by saline water had comparable live body weight of ewes for control group. This slight reduction in daily gain of animals fed on halophytes fodder might be attributed to the tannins content which was found to reduce the digestibility of protein and dry matter (Priolo et al., 2000 and El-Shaer, 2010). A combination of reduced intake and low true digestibility of protein cause the negative effect of tannins on growth rate (Ben Salem et al., 2010, El- Shaeret al., 2005 and El- Shaer 2010).

\section{Economic efficiency:}

Results in Table (6) showed that, the lowest total feed cost/rabbit $(2.078 \mathrm{LE})$ was observed with rabbits fed $100 \%$ freshwater kochia (maintenance and growth), followed by that fed $25 \%$ saline water kochia, $75 \%$ freshwater kochia for (Growth requirement) while fed granular feed to cover (maintenance 
requirement). Results also, revealed that groups fed the diets contained kochia were provided the highest economic efficiency (10.91 and 3.01) respectively, than the control group (1.55), which fed diets contained $100 \%$ granular feed. Also, the relative economic efficiency was higher in groups fed on kochia (703.87 and 194.19) for G2 and G3 respectively, compared to the control group G1 (100).

Generally, it can be noticed that rabbit fed on the diets contained kochia (G2 and G3) had higher economic return than control group (fed $100 \%$ granular feed). These results were in agreement with Youssef et al. (2009) who fed two hays of salt tolerant plants (Kochia indica and Pearl millet) grass and their mixture to sheep under saline conditions. They found that feeding growing sheep on tolerant plants decreased the daily feed cost (LE/head) and these materials whould be economic since it reduced the feed cost.

Table (6): Effect of experimental treatments on economic efficiency of growing rabbits.

\begin{tabular}{lccc}
\hline Item & $\mathrm{G} 1$ & $\mathrm{G} 2$ & $\mathrm{G} 3$ \\
\hline Final weight & 1493.75 & 1237.14 & 1020.00 \\
Price of 1 kg body weight & 20 & 20 & 20 \\
Selling price/rabbit (LE) A & 29.88 & 24.74 & 20.40 \\
Total granular feed intake/kg & 4.692 & 0 & 1.643 \\
Total kochia intake/kg & 0 & 3.464 & 1.643 \\
Granular feed cost/LE & 11.73 & 0 & 4.108 \\
Kochia cost/LE & 0 & 2.078 & 0.986 \\
Total feed cost/rabbit (LE) (B) & 11.73 & 2.078 & 5.094 \\
Net revenue (LE) $^{1}$ & 18.15 & 22.66 & 15.31 \\
Economic efficiency $^{2}$ & 1.55 & 10.91 & 3.01 \\
Relative Econ. Eff. $^{3}$ & 100 & 703.87 & 194.19 \\
\hline
\end{tabular}

(1) Net revenue $=A-B$.

(2) Economic efficiency $=(A-B / B)$.

(3) Relative Economic efficiency = Economic efficiency of treatments other than the control / Economic efficiency of the control group.

- G1 $=$ fed $100 \%$ granular feed (growth and maintenance requirements), G2 $=$ fed $100 \%$ fresh kochia (growth+ maintenance) from fith to eleventh weak, G3 = fed 25\% saline kochia, $75 \%$ fresh kochia (Growth), in addition to Granular feed to cover maintenance requirements

\section{CONCLUSION}

Using kochia as a rabbits feed led to reduce feeding cost and generally improve feed efficiency. However, more studies are required to investigate the effect of saline and fresh kochia as a halophytes fodder in the feed for rabbits.

\section{ACKNOWLEDGMENT}

Recording our deep thanks to Prof. Dr. Hesham Ibrahim El kassas Prof and head of Agriculture Environment - Institute of Environmental Studies and Research - Ain Shams University, and Dr. Mahmoud Abd Elkawy Zahran Assistant Professor of plant Environment, Faculty of Science, Mansoura University, for their valuable criticism and guidance through this work.

\section{REFERENCES}

Ajjour, R. A. (2005). Influence of salinity inirrigation water and nitrogen fertilizer on koshia (Kochia scoparia) and soil chemical properties. Master thesis, Jordan University, Amman. Jordan.

Al-Dabbas, M. (2001). Use of Saline Water for Agricultural Purpose. Amman, Jordan. 


\section{Elsayed et al.}

Anon (2006). Electronic Conference on salinization: Extent of salinization and strategies for salt-affected land prevention and rehabilitation, 6 February-6 March 2006. Organized and coordinated by IPTRID (International programme for technology and Research in irrigation and Drainage), FAO.

Anon (2009). Introduction of salt-tolerant forage production systems to salt-affected lands in Sinai Peninsula in Egypt: a pilot demonstration project. Final Report, DRC, Egypt-ICBA, UAE.

A.O. A. C. (1995). Official methods ofanalysis. 15th ed. Association of Official Analytical Chemists. Arlongton, Virginiall USA.

Bayoumi, A. S.; A. Incecik; H. El Gamal and K. Shalash (2010). Wave Powered Water Desalination in Egypt, Fourteenth International Water Technology Conference, IWTC 14, Cairo,Egypt: 191.

Ben Salem, H.; H.C. Norman; A. Nefzaoui; D.E. Mayberry; K.L. Pearce and D.K. Revell, (2010). Potential use of oldman saltbush (AtriplexnummulariaLindl.) in sheep and goat feeding. Small Ruminant Research, 91: 13- 28.

Catherine, L. and R. Hubert (2005). Selection for residual feed consumption in the rabbit, Livestock Production Science 95 : 67-72

Duncan (1955). Multiple range and multiple F test . Biometric, 11: 1-42.

El-Shaer, H.M., (2010). Halophytes and salt tolerant plants as potential forage for ruminants in the Near East region. Small Ruminant Res. 91, 3-12.

El Shaer, H. M.; Ali, F. T.; Morcos, N. Y. S.; Emam, S. S. and Essawy, A. M. (2005). Seasonal changes of some anti-nutritional factors contents of some halophytic shrubs and the effect of processing treatments on their utilization by sheep under desert conditions of Egypt. Egyptian J. Nutr. Feeds, 8 (1): Special Issue: 417- 431.

Hamdy, A. (2001). Advanced short course on: Water saving and increasing water productivity: challenges and options. University of Jordan, Amman- Jordan.

Khalifa, E. (2005)Safe Wastewater Use in Agriculture in Egypt, Minister's Technical Office, Ministry of Water Resources andIrrigation, Egypt: 1-6.

Miller, J. E., (2003). Review of water resources and desalination technologies, Sandia National Lab.,: 6.

Mohammady, M. I.; A. H. Hammam and N. H. Ibrahim (2014).Returns and economical efficiency of Barki sheep fed on salt tolerant plants in Sinai, Egypt. The Journal of American Science; 2014. 10(4):134-139. 11

NRC (1977). National Research Council, Nutrient Requirements of rabbits. Washington, DC., U.S.A.

Priolo, A.; Waghorn, G. C.; Lanza, M.; Biondi, L. and Pennisi, P. (2000). Polyethylene glycol as means for reducing the impact of condensed tannins and carob pulp: effects on lambs growth performance and meat quality. J. Anim. Sci., 78 (4): 810.

SAS (1995). SAS User's Guide: Statistics (Version 6.10). SAS Inst. Inc.,Cary, NC.7

Shaker, Y. M. (2014).Live body weight changes and physiological performance of Barki sheep fed salt tolerant fodder crops under the arid conditions of Southern Sinai, Egypt. The Journal of American Science; 2014. 10(2s):78-88.

Semioshkina, N. A. ; A. G. Proehl; B. Savinkov and G. Voigt, (2007). The transfer of Cs and Sr from feed to rabbitsJournal of Environmental Radioactivity $98: 166-176$.

Undersander, D.J., B.R. Durgan; A.R. Kaminsk; J.D. Doll; G.L. Worf and E.E. Schulte (2004). Kochia. Alternative Field Crops Manual. Retrieved from: http://www.hort.purdue.edu/newcrop/default.html

Youssef, K.M.; A. A. Fahmy; Abeer M. El-Essawy and H. M. El-Shaer (2009). Nutritional studies on pennisetum americanum and Kochia indica fed to sheep under saline conditions of Sinai, Egypt. American Eurasian j. Agric. \& environ. Sci., 5 (1): 63-68, 2009.

Zarkawi, M.; M.R. Al-Masri, and K. Khalifa, (2005). Nutritive value of Sesbania aculeate grown on salty soil and its effect on reproductive parameters of Syrian Awassi ewes. Aust. J. of Anim. Res., 56 (8): pp. 819-825. 


\title{
تأثير التذذية على كوخيا المياة العذبة أو المالحة كمصدر علف فى علائق الارانب النامية
}

\author{
حمدي محم السيد1 و أحمد عبد الله مروان أو ياسر ابراهيم ابراهيم²

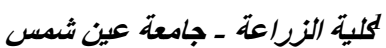 \\ جوزارة الصحة والسكان
}

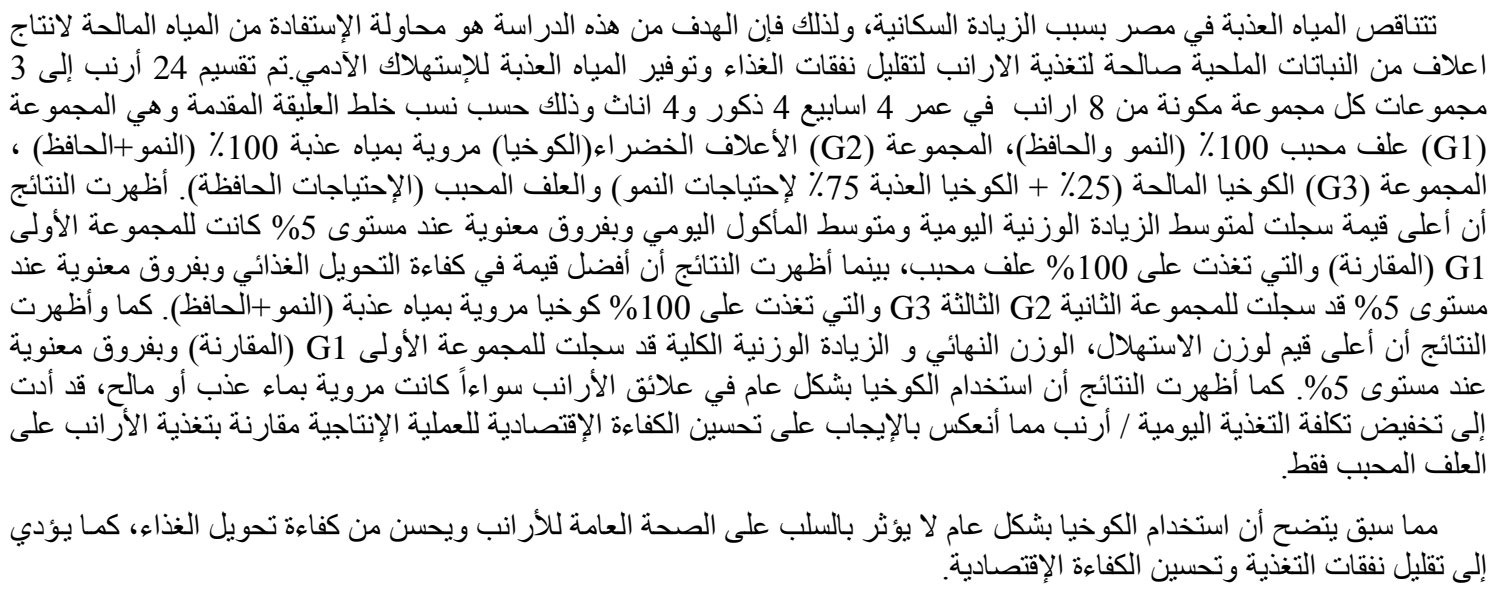

